\title{
Growth and wool production of sheep reared at highland of Nepal
}

\author{
B Khanal ${ }^{1 *}$, AKMA Kabir ${ }^{2}$, BR Baral ${ }^{1}$ and HR Dhakal ${ }^{1}$
}

Affiliation: ${ }^{1}$ Sheep and Goat Research Program, Guthichaur, Jumla, Nepal; ${ }^{2}$ Department of Animal Science, Bangladesh Agricultural University, Mymensingh-2202, Bangladesh.

\begin{abstract}
Sheep farmers lived in high altitude of Nepal have limited options of supplying roughages in winter season which is resulting severe feed deficit in these periods. Quality roughages like hay and other dried cereal stalks are not sufficiently available in the areas to mitigate the feed deficit in dry harsh winter. Therefore, the study was conducted to evaluate the effects of commonly practiced feeding system on growth and wool production of sheep in winter season. The research was performed at Sheep and Goat Research farm, Jumla, Nepal which is located at 2700 meters above sea level. The animals were supplied with three different rations viz (i) adlibitum oat hay with concentrate feed @ $1 \%$ of body weight;(ii) adlibitum conventional hay with concentrate feed @1\% of body weight, and (iii) grazing in moderate pasture with concentrate feed @ $1 \%$ of body weight. The differences among the treatments were found significant $((p<0.05)$ changes in terms of average daily weight gain and total weight gain, while wool length and wool production were not significantly different $(p>0.05)$ among the treatments. The treatment of feeding oat hay with concentrate @ $1 \%$ of body weight had yielded highest body weight gain. The result of the study revealed that feeding oat hay was more profitable in comparison to conventional system of grazing and feeding conventional hay. Inclusion of oat hay on the sheep diet in dry harsh winter season could make substantial improvement in the body weight gain of the sheep in the high altitude of Nepal.
\end{abstract}

Key words: hay, sheep, weight gain, wool, Nepal

Bangladesh Animal Husbandry Association. All rights reserved.

Bang. J. Anim. Sci. 2017. 46 (3): 159-163

\section{Introduction}

Sheep are one of the most important ruminant animals for livelihood of hill and mountain of the Nepal.The total population of sheep of the country is 789292 (CBS, 2016). Baruwal sheep (Capra ovis) is the major native breed type of Nepal with 63 percent of the total national herd and grown in the mountain up to $3000 \mathrm{~m}$ above sea level.They are good grazing instinct and suitable for migratory system. It is popular for coarse wool that is used to produce radi, pakhi, lieu.Lamb meat (mutton) is an excellent protein source and provides important minerals such as iron and zinc (Williams, 2007). It is generally known that raising young animals on high concentrate diets results in higher daily gains, dressing percentage and carcass quality than on a forage system (Johnson et al., 2005). The productivity of sheep can be improved by improving the nutrition either concentrate feeding or provision of additional forage. Feeding and management system affect on productivity of animals. During the winter at high hill there is very cold, can't fed sufficient under traditional grazing management system.
Hay is the typical diet for ruminant animals during this time. Most of the farmers follow the grazing and fed little amount of conventional hay to the sheep. During the cold season, grazing animals survived from inadequate herbage, low temperature and cold environment as a result low growth rate and even death of grazing livestock (Sun et al., 2015). If not provide additional concentrate or quality forage weight gain may be in minus during winter season at high hill. Feed efficiency and the off-take rate of livestock were quiet low under traditional grazing management (Zhao and Zhou, 1999). Therefore, the study was conducted to evaluate the effects of commonly practiced feeding system on growth and wool production of sheep in winter season for the better improvement of sheep farming in Nepal.

\section{Materials and Methods}

\section{Location and animals}

This experiment was carried out at 2700 masl at Sheep and Goat Research Program, Guthichaur, Jumla, Nepal for 90 days from mid October to mid January, 2015 on18 male Baruwal sheep aged, 10 to 11 months. Male sheep having same

*Corresponding author: birkhanal@gmail.com 
Khanal et al. (2017) Bang. J. Anim. Sci. 46 (3):159-163

age of average $18.13 \mathrm{~kg}$ were allocated into three groups having six animals in each group using completely Randomized Design (CRD). Animals were de-wormed against internal parasites by febendazole @ $5 \mathrm{mg} / \mathrm{kg}$ body weight before the experimental trial. The experimental animals were placed in house partitioned into individual pen that is equipped with feeding trough and watering bucket. Animals were adapted to the experimental procedures and feeds for 7 days before the commencement of the trials.

\section{Experimental diets}

Oats and conventional grasses were cut at 50\% flowering stage to make hay. The prepared conventional hay and oat hay was used for treatment groups 1 and 2, respectively and another group (group 3) was allowed to graze. Grazing was usually done about 8 hours a day. For all the animals, $1 \%$ on the basis of their body weight concentrate mixture was supplied. Treatments details were:

$\mathrm{T}_{1}$ : Feeding conventional hay with concentrate;

$\mathrm{T}_{2}$ : Feeding oat hay with concentrate, and

$T_{3}$ : Grazing with concentrate

\section{Data measurement and analysis}

Initial live weight, monthly live weight, initial length of wool, final length of wool and wool production was recorded. Costs of input and prices of products were also recorded for economic analysis. All the data obtained in the experiment were subjected to statistical analysis using MSTAT for analysis of variance and Duncan's multiple range test.The samples of feeds were sent to Animal nutrition division, Khumaltar, Lalitpur for proximate analysis

\section{Results and Discussion}

\section{Chemical composition of feeds}

Table 1 indicates the chemical composition of feed. It was found that among the dry roughages, oat hay contained maximum crude protein (CP) as compared with conventional hay. Concentrate feed had $16 \% \mathrm{CP}$ and $1 \% \mathrm{Ca}$. Low $\mathrm{CP}$ contained in conventional hay needed to support acceptable ruminal microbial activity and the production requirement of the host ruminant but there was no probability to supply additional $\mathrm{CP}$ on fresh basis.
Table 1.Chemical composition of feed

\begin{tabular}{llllll}
\hline Content & DM & CP & NDF & ADF & Ca \\
\hline $\begin{array}{l}\text { Conventional } \\
\text { hay }\end{array}$ & 90.7 & 5.5 & 75.3 & 40.35 & 0.41 \\
Oat hay & 89.6 & 7.4 & 76.2 & 40.75 & 0.56 \\
Concentrate & 91.4 & 16 & 60 & 35.34 & 1.0 \\
\hline
\end{tabular}

\section{Weight gain}

The data on weight gain were presented in Table 2. The data obtained of average daily weight gain and total weight gain on different groups have significant differences $(p<0.05)$. It was found that maximum weight gain $(41.07 \mathrm{~g} / \mathrm{day} / \mathrm{sheep})$ was obtained from feeding oat hay with concentrate @ $1 \%$ of BW $\left(T_{2}\right)$ followed by $\left(T_{1}\right)$ feeding conventional hay with concentrate @ $1 \%$ of BW (30.14 g/day/sheep)and the lowest (22.11 $\mathrm{g} /$ day/sheep) was obtained by conventional grazing system $\left(T_{3}\right)$. Total highest weight gains between groups $(3.70 \mathrm{~kg} / \mathrm{sheep})$ were observed from fed $T_{2}$ diet followed by $T_{1}$ diets $(2.71 \mathrm{~kg} /$ sheep) and the lowest $(1.99 \mathrm{~kg} / \mathrm{sheep})$ by $\mathrm{T}_{3}$ diets.

The finding was supported by many authors. Rasli (1995) found that under transhumance system in high hill, the body weight gain of Baruwal sheep of age at 12 month were $47.0 \pm 0.6 \mathrm{~g} /$ day to $49.2 \pm 0.09 \mathrm{~g} /$ day. When only grazing on forages is provided, it may not be sufficient for optimum live weight gain and wool production (Kochapakdee et al., 1994). When lambs are raised on pasture, the available forage mass can influence intake, performance and body weight (Turner et al., 2014).Hassen et al. (2004) mentioned that management options (feeding strategies and mating systems) including alternative breeding programs enhanced sheep productivity. An adequate amount of roughage is necessary in total mixed ration for proper structural and functional development of the rumen (Van Ackeren et al., 2009). Koyuncuet et al. (1996) obtained higher dressing percentage (42.2 vs $36.8 \%$ ) from housed than extensively reared goats. Average dressing percentages were $42.18,39.0,36.79$ and 34.0 for stall feeding, tethering, restricted grazing and grazing groups, respectively. Dressing percentages varied significantly (Moniruzzaman et al., 2002).Concentrate feeding to Baruwal ewes improved their body weight and maintained condition in migratory system (Dhaubhadel, 2000). Weight gain during severe winter season in our finding is supported by this finding. Stall 


\section{Production performance of sheep in hilly areas of Nepal}

feeding had better growth rate of kids than open grazing system of rearing. Under stall fed condition, average weight gain ranged from $8.67 \mathrm{~g} /$ day to $11.33 \mathrm{~g} /$ day whereas in open grazing system weight gain was $4.87 \mathrm{~g} /$ day to $8.33 \mathrm{~g} /$ day in different belts (Pariyar, 2006). Barakoti and Sapkota (2008) founded that grazing for 8 hours without additional feeding supplement was more effective for increasing body weight than Para and Napier feeding without grazing. Grazing for 4 hours with ipil ipil adlib feeding resulted higher meat production. This study supplied the green fodder. Therefore adverse result was obtained than our study. The reasons behind less weight gain in $T_{3}$ and $T_{1}$ than $\mathrm{T}_{2}$ diets may be due to poor availability and digestibility of grass and ultimately the sheep could not achieve optimum growth rate. Rapidly growing sheep have greater needs for protein than do animals just maintaining weight.

Table 2. Live weight changes of sheep fed different types of diet

\begin{tabular}{|c|c|c|c|c|c|}
\hline \multirow[t]{2}{*}{ Treatments } & \multicolumn{3}{|c|}{ Average daily weight gain, g } & \multirow{2}{*}{$\begin{array}{l}\text { Total average daily } \\
\text { weight gain, } g\end{array}$} & \multirow{2}{*}{$\begin{array}{l}\text { Total } \\
\text { weight } \\
\text { gain, kg }\end{array}$} \\
\hline & $30^{\text {th }}$ day & $60^{\text {th }}$ day & $90^{\text {th }}$ day & & \\
\hline $\begin{array}{l}\text { Conventional hay } \\
\text { with concentrate@ } \\
1 \% \text { of } \mathrm{BW}\left(\mathrm{T}_{1}\right)\end{array}$ & $25.73^{\mathrm{ab}}$ & $30.03^{b}$ & $34.67^{b}$ & $30.14^{b}$ & $2.71^{\mathrm{b}}$ \\
\hline $\begin{array}{l}\text { Oat hay with } \\
\text { concentrate @ } 1 \% \\
\text { of } \mathrm{BW}\left(\mathrm{T}_{2}\right)\end{array}$ & $32.85^{\mathrm{a}}$ & $42.63^{a}$ & $44.74^{a}$ & $41.07^{\mathrm{a}}$ & $3.70^{\mathrm{a}}$ \\
\hline 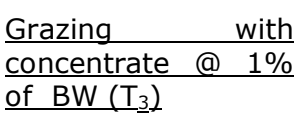 & $22.45^{\mathrm{b}}$ & $24.45^{\mathrm{c}}$ & $19.44^{\mathrm{c}}$ & $22.11^{\mathrm{c}}$ & $1.99^{\mathrm{C}}$ \\
\hline Mean & 28.01 & 32.37 & 32.95 & 31.11 & 2.80 \\
\hline CV\% & 8.46 & 11.57 & 9.38 & 9.80 & 10.42 \\
\hline $\operatorname{LSD}_{(0.05)}$ & 6.85 & 8.7 & 8.04 & 7.86 & 0.68 \\
\hline $\mathrm{SEM} \pm$ & 3.04 & 3.45 & 3.9 & 3.46 & 0.33 \\
\hline
\end{tabular}

Note: CV, Coefficient of variation; LSD, Least significant difference; SEM, Standard error of the mean and NS, Non significant. Superscripts $a, b$, and c means significant values within the rows.

Table 3. Average wool length gain $(\mathrm{cm})$ and production $(\mathrm{g})$

\begin{tabular}{|c|c|c|}
\hline Treatments & $\begin{array}{l}\text { Wool length } \\
\text { gain/sheep, cm }\end{array}$ & $\begin{array}{c}\text { Wool production/sheep, } \\
\mathrm{g}\end{array}$ \\
\hline Conventional hay with concentrate@ $1 \%$ of $B W\left(T_{1}\right)$ & 7.9 & 436 \\
\hline Oat hay with concentrate@1\% of BW $\left(T_{2}\right)$ & 8.7 & 465 \\
\hline Grazing with concentrate@ $1 \%$ of $\mathrm{BW}\left(\mathrm{T}_{3}\right)$ & 7.8 & 453 \\
\hline Mean & 8.13 & 451 \\
\hline CV\% & 13.21 & 12.59 \\
\hline $\operatorname{LSD}_{(0.05)}$ & NS & NS \\
\hline $\mathrm{SEM} \pm$ & 1.8 & 12.46 \\
\hline
\end{tabular}

Note: CV, Coefficient of variation; LSD, Least significant difference; SEM, Standard error of the mean and NS, Non significant. Superscripts $a, b$, and c means significant values within the rows. 


\section{Wool production}

Table 3 indicates the average wool length gain and wool production. The data obtained from this study shown that the staple length of wool and wool production/sheep have significantly non differences $(p>0.05)$. The increment of wool length $(8.7 \mathrm{~cm})$ was found high by $T_{2}$ diets followed by $T_{1}$ diets $(7.9 \mathrm{~cm})$ and the least $(7.8$ $\mathrm{cm}$ ) was obtained from $\mathrm{T}_{3}$ diets. The highest average wool production (465 $\mathrm{g} /$ head) was obtained from $T_{2}$ diets followed by $T_{3}$ diets ( 453 $\mathrm{g} / \mathrm{head}$ ) and the least(436 $\mathrm{g} / \mathrm{head}$ ) was obtained from $\mathrm{T}_{1}$ diets. The finding on difference wool length and wool production was supported by many authors. The main components affecting efficiency of wool production are intake, nutritive value of feed, body weight and season (Butler and Maxwell, 1984).The level of nutrition affects the wool production and efficiency (Ferguson, 1972).Shrestha (2006) found that wool yield was found more during autumn shearing $(0.67 \pm 0.19$ $\mathrm{kg}$ ) followed by spring shearing $(0.54 \pm 0.25 \mathrm{~kg})$. This higher yield of wool production was contradicted with our study. The reason behind less wool production in our study as compared to this study will be due to earlier shearing of wool. Higher wool length increment and more wool production were obtained from $\mathrm{T}_{2}$ as compared to others diets, may be due to higher nutritional status of oat hay than other grasses.

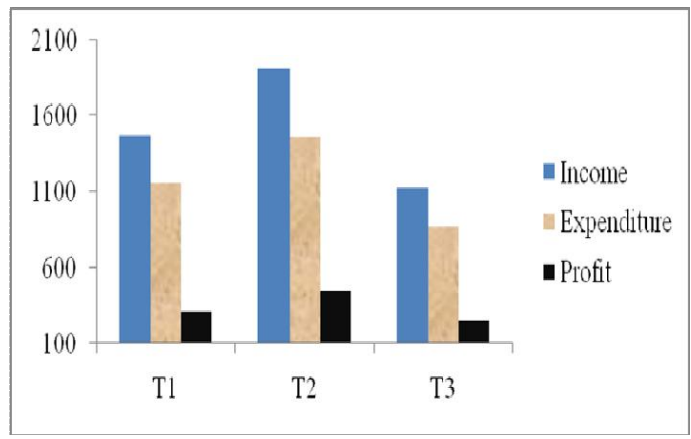

Figure 1. Profit gained by sheep farmers (Note: NRs $98=\$ 1$ ).

\section{Economic benefit}

Farmers suffered huge economic loss due to serious live weight loss in grazing animals during winter season. In our study, it was found that profit directly affected by weight gain. Figure 1 indicates the profit gained by farmers during three month. It was found that oat hay feeding was more profitable as compared with others diet. The highest income (NRs $450.87 /$ sheep) was obtained in $T_{2}$ group followed by $T_{1}$ (NRs $314.90 /$ sheep) and the least income (NRs 254.63 /sheep) was obtained by $\mathrm{T}_{3}$ group. As compared with $T_{3}$ and $T_{1}$ diets more income NRs 196.24/sheep and NRs 135.97/sheep, respectively was obtained by $T_{2}$ diets. Higher nutritive feed including $\mathrm{CP}$ dietary and warm environment on stall shed contributed to higher weight gain that affected on net economic benefit in sheep was determined in this study.

\section{Conclusion}

Average daily weight gain and average total weight gain of sheep was very low under traditional grazing system during winter season. The data were shown that daily weight gain and flock weight gain have significantly differences $(p<0.05)$. Differences on wool length and wool production were not statistically significant $(p>0.05)$. The result of the study revealed that feeding oat hay was more profitable as compared with conventional system of grazing and feeding conventional hay. Inclusion of oat hay on the sheep diet in dry harsh winter season could make substantial improvement in the body weight gain of the sheep in the high altitude of Nepal.

\section{Acknowledgement}

I would like to express my thanks to Dr. Megh Raj Tiwari, Director of Mountain Agricultural Research Institute for his help on various suggestions during research period. I would like to extend my thanks to Dr. Bodh Raj Baral and Mr. Hem Raj Dhakal for their help in collecting data as well as preparation this report.

\section{References}

Barakoti TP and M Sapkota (2008). Effect of grazing and feeding combination on castrated goats. The $5^{\text {th }}$ national conference on science and technology. Nepal academy of science and technology (NAST), Kathmandu, Nepal.10-12 Nov. p12-17.

Butler LG and MMC Maxwell (1984). A review of the efficiency of conversion of feed into wool. Animal breeding abstracts 52:475-485.

CBS (2016). Statistical year book Nepal 2015. Central bureau of statistics Ramshahpath, Thapathali, Kathmandu, Nepal. p 207.

Dhaubhadel TS (2000). Stress caused by shortage of winter feed as constraint upon the migratory system of sheep management 


\section{Production performance of sheep in hilly areas of Nepal}

in the western hills of Nepal. Proceeding of the $3^{\text {rd }}$ national animal science convention (NASA), Nepal.27-28 Aug. p 97-102.

Ferguson KA (1972). The nutritional value of diets for wool growth. Proceedings of the Australian society of animal production. 9:314-320.

Hassen Y, J Solknerand WB Fuerst (2004).Body weight of awassi and indigenous Euthopian sheep and their crosses. Small Ruminant Research 55(1-3):51-56.

Hossain ME, M Shahjalal, $M J$ Khan and AA Bhuiyan (2003).Effect of dietary energy supplementation on feed intake, growth and reproductive performance of sheep under grazing condition. Pakistan Journal of Nutrition 2:148-152.

Johnson PL, RW Purchas, JC Mcewan and HT Blair (2005). Carcass composition and meat quality differences between pasture reared ewe and ram lambs. Meat Science 71:383391.

Kochapakdee S, W Pralokarn, S Saithanoo, ALaapetchara and BW Norton (1994). Grazing management studies with Thai goats. Productivity of female goats grazing newly established pasture with varying levels of supplementary feeding. Asian Australasian Journal of Animal Science 7:289-294.

Koyuncuet M, E Tuncel and N Akman (1996). Fattening performance and carcass characteristics of male angora kids under intensive and pasture conditions. Turkveterinerlik-vehayvancilik-dergisi 20(3):157161.

Moniruzzaman M, MA Hashem, S Akhter and MM Hossain (2002). Effect of different feeding systems on carcass and non-carcass parameters of black Bengal goat. Asian Australasian Journal of Animal Science 15(1):61-65.
Pariyar D (2006). An effective goat rearing model for poor farmers for poverty alleviation. Proceeding of the $6^{\text {th }}$ national workshop on livestock and fisheries research in Nepal. 1-2 July, 2004.p 70-71.

Rasli DP (1995). Comparative performance of Baruwal and $25 \%$ border leicester $\times 75 \%$ Baruwal yearlings lambs under a transhumance system in the high hills. Proceeding of the $2^{\text {nd }}$ national animal science convention (NASA), Nepal. 7-10 Aug, 1995. p 85-91.

Shrestha YK (2006). Productive and reproductive performance of different genotypes of sheep at Guthichaur.Proceeding of $6^{\text {th }}$ national workshop on livestock and fisheries research in Nepal. 1-2 July, 2004.p33-36.

Sun Y, JP Angerer and FJ Hou (2015). Effects of grazing systems on herbage mass and live weight gain of Tibetan sheep in eastern qinghai-tibetan plateau, China. Range land Journal 37:181-190.

Turner KE, DP Belesky, KA Cassida and HN Zerby (2014). Carcass merit and meat quality in Suffolk lambs, Katahdin lambs, and meatgoat kids finished on a grass legume pasture with and without supplementation. Meat Science 98:211-219.

Van Ackeren C, H Steingab, K Hartung, R Funk and W Drochner (2009). Effect of roughage level in a total mixed ration on feed intake, ruminal fermentation patterns and chewing activity of early-weaned calves with ad libitum access to grass hay. Animal Feed Science and Technology 153:48-59.

Williams P (2007). Nutritional composition of red meat. Nutrition Diet 64:113-119.

Zhao XQ and XM Zhou (1999). Ecological basis of alpine meadow ecosystem management in Tibet: Haibei alpine meadow ecosystem research station. Ambio- A Journal of the Human Environment 28(8):642-647. 